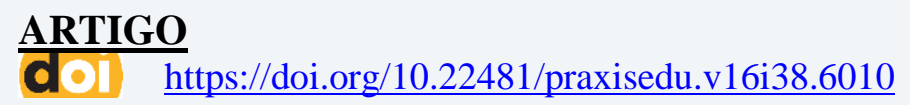

\title{
BLENDED LEARNING, INNOVATIVE PATTERN IN TEACHERS PROFESSIONAL DEVELOPMENT IN EDUCATIONAL SYSTEM OF IRAN
}

\author{
APRENDIZAJE COMBINADO, PATRÓN INNOVADOR EN EL DESARROLLO \\ PROFESIONAL DE DOCENTES EN EL SISTEMA EDUCATIVO DE IRÁN
}

BLENDED LEARNING, PADRÃO INOVADOR NO DESENVOLVIMENTO

PROFISSIONAL DE PROFESSORES NO SISTEMA EDUCACIONAL DO IRÃ

\author{
Mahboubeh Fannakhosrow \\ University of Tehran - Iran \\ Soolmaz Nourabadi \\ Shahed University - Iran
}

\begin{abstract}
Resumo: O desenvolvimento das TIC e a aplicação de novos instrumentos e conceitos por meio da comunicação on-line, oferecem oportunidades incomparáveis para troca rápida de informações e interações sociais para os alunos e causam expansão da informação, acesso fácil, rápido e de baixo custo. A instituição de ensino, como guardiã da educação e do treinamento, pode ser responsável pela produção de conhecimento e eficiência no processo educacional, aumentando assim o conhecimento de alunos e professores. Portanto, este estudo tem como objetivo combinar o aprendizado eletrônico com o aprendizado tradicional e fornecer aprendizado combinado no desenvolvimento profissional dos professores. Como a missão mais importante da educação é a capacitação de recursos humanos capaz e eficiente, recomenda-se o uso de estudos e experiências anteriores e, contando com a cultura e as fontes indígenas, deve responder a essa pergunta se o aprendizado combinado pode ser usado como um padrão inovador no desenvolvimento profissional dos professores no sistema educacional do Irã. Para responder a essa pergunta, a presente pesquisa foi realizada com o método descritivo-analítico. Agora, com o uso da moderna tecnologia da informação e comunicação, além dos tutoriais virtuais online, simultânea ou não-simultânea, é formado um novo tipo de treinamento, o Blended Learning, que é combinado às salas de aula tradicionais e refere-se ao território onde tradicional e eletrônica o aprendizado é usado tanto para treinar os alunos. Usando a Internet e os sistemas multimídia, uma variedade de ferramentas pode ser fornecida para melhorar a qualidade da aprendizagem e também o acesso rápido e fácil aos recursos de informação e, com atividades presenciais, podem ser preparados elementos de interação no treinamento. Assim, com a ajuda das tecnologias e da mídia digital e da criação de um currículo centrado no aluno, a concepção de casos, ensino, aprendizagem, avaliação e avaliação no ambiente de aprendizado eletrônico será otimizada. Uma das necessidades dos sistemas educacionais na era da informação é o cultivo de professores sábios e atenciosos em instituições de treinamento de professores que são competentes para resolver problemas modernos da educação e inovar soluções criativas. O topo da forma para esse fim, o aprendizado misto (baseado em rede) por meio de novos métodos de treinamento, fornece a base necessária para melhorar a qualidade da
\end{abstract}


educação e o treinamento de professores sofisticados e fornece uma maneira eficaz de alcançar as metas proeminentes da educação. A instrução combinada mudou as oportunidades educacionais e as ferramentas práticas também estão disponíveis para professores e designers de instrução.

Palavras chave: TIC, E-Learning, Blended Learning, Desenvolvimento Profissional de Professores.

\begin{abstract}
ICT development and application communication, provides unmatched

of new instruments and concepts through online opportunity for rapid exchange of information and social interactions for learners and causes expansion of information, easy, fast and low cost access. Education institution as custodian of the education and training can be responsible for the production of knowledge and efficiency in the education process, thereby increasing the knowledge of learners and teachers. So this study aims to combine E-learning with traditional learning and to provide blended learning in teachers' professional development. Since the most important mission of education, is capable and efficient human resources training, it is recommended to use the previous studies and experiences and by relying on culture and indigenous sources, should answer this question whether the blended learning can be used as an innovative pattern in teachers' professional development in educational system of Iran. To answer this question, the present research was carried out with descriptive-analytical method. Now with the use of modern information and communication technology,in addition to online virtual tutorials simultaneously or non-simultaneously, a new type of training, namely Blended Learning, is formed which is combined to traditional classrooms and refers to the territory where traditional and electronic learning is used both for training the learners. Using the Internet and multimedia systems, a variety of tools can be provided to improve the quality of learning and also quick and easy access to information resources and with face to face activities can be prepared interaction element in training. Thus, with the help of technologies and digital media and designing learner-centered curriculum, designing affair, teaching, learning, assessment and evaluation in the electronic learning environment will be optimized. One of the educational systems' necessities in the information era, is cultivation wise and thoughtful teachers in teacher training institutions who are competent in solving modern problems of education and innovating creative solutions. Top of form for this purpose, blended learning (network-based) through new training methods, provides the necessary foundation for improvement the quality of education and training sophisticated teachers and provides effective way to achieve the prominent goals of education. Blended instruction, have changed educational opportunities and the practical tools are available to teachers and instructional designers as well.
\end{abstract}

Key words: ICT, E-Learning, Blended Learning, Teacher Professional Development.

Resumen: El desarrollo de las TIC y la aplicación de nuevos instrumentos y conceptos a través de la comunicación en línea, brinda una oportunidad inigualable para un rápido intercambio de información e interacciones sociales para los alumnos y provoca la expansión de la información, acceso fácil, rápido y de bajo costo. La institución educativa como custodio de la educación y la formación puede ser responsable de la producción de conocimiento y eficiencia en el proceso educativo, aumentando así el conocimiento de los alumnos y los docentes. Por lo tanto, este estudio tiene como objetivo combinar el aprendizaje electrónico con el aprendizaje tradicional y proporcionar un aprendizaje combinado en el desarrollo profesional de los docentes. Dado que la misión más importante de la educación es la capacitación de recursos humanos capaz y eficiente, se recomienda utilizar los estudios y experiencias previas y, al depender de la cultura y las fuentes indígenas, debería responder a esta pregunta si el aprendizaje combinado puede usarse como un patrón innovador en el desarrollo profesional de docentes en el sistema educativo de Irán. Para responder a esta pregunta, la presente investigación se realizó con un método descriptivo-analítico. Ahora, con el uso de tecnología moderna de información y comunicación, además de tutoriales virtuales en línea de forma simultánea o no simultánea, se forma un nuevo tipo de capacitación, a saber, Blended Learning, que se combina con 
las aulas tradicionales y se refiere al territorio donde tradicional y electrónico el aprendizaje se usa tanto para entrenar a los alumnos. Utilizando Internet y sistemas multimedia, se pueden proporcionar una variedad de herramientas para mejorar la calidad del aprendizaje y también se puede preparar un acceso rápido y fácil a los recursos de información y con actividades presenciales elemento de interacción en la capacitación. Por lo tanto, con la ayuda de las tecnologías y los medios digitales y el diseño de un plan de estudios centrado en el alumno, se optimizará el diseño de asuntos, enseñanza, aprendizaje, evaluación y evaluación en el entorno de aprendizaje electrónico. Una de las necesidades de los sistemas educativos en la era de la información, es cultivar maestros sabios y reflexivos en instituciones de capacitación docente que sean competentes para resolver problemas modernos de educación e innovar soluciones creativas. Para este propósito, el aprendizaje combinado (basado en la red) a través de nuevos métodos de capacitación, proporciona la base necesaria para mejorar la calidad de la educación y la capacitación de docentes sofisticados y proporciona una forma efectiva de lograr los objetivos destacados de la educación. La instrucción combinada, ha cambiado las oportunidades educativas y las herramientas prácticas también están disponibles para los maestros y diseñadores de instrucción.

Palabras clave: TIC, E-Learning, aprendizaje combinado, desarrollo profesional docente.

\section{Introduction}

Over the past few decades, due to changes caused by technology in policy making and educational planning, there has been a significant improvement in the quality of education that emphasizes learning technology or teaching technology to learn technology, and its purpose is to create creativity and the ability to create knowledge by the learner.

On the other hand, E-learning can lead to balanced education and provide equal educational opportunities for all to exclude the educational process from monopoly engagement. The E-learning environment can provide the conditions that teacher can judge learners performance without affected from specific characteristics of them. In the E-learning environment, individuals are known in terms of the extent of their presence in the virtual learning environment, as well as the quantity and quality of the activity that they are learning to learn. So other factors like individual characteristics and interpersonal skills, cannot affect the way of evaluation (Noroozi and Razavi, 2014).

With the development of E-commerce and the Internet and its application in the field of education, designers and educators have tried to use these technologies to solve educational problems and improve quality (Florence Mihaela Singera \& Daniela Stoicescu, 2010; R. Donnelly, 2010). Some scholars believe that the communication, multimedia, and information capabilities of these technologies can provides a platform for combining the capabilities of these two environments and create new learning environments in addition to strengthening inperson training and the formation of web-based and E-learning environments (Omer 
Deperliglu \& Utku Kose, 2010; Bridget Melton., Helen Graf \& Joanne Chopak.Foss, 2009) (Seraji and Attaran, 2011).

The emergence of E-learning, besides being the basis for rethinking about education and learning, has provided facilities for educational designers to apply many of their ideas.The learner-based and the learner's active curriculum is potential that can be used in electronic environments. In learner-based curriculum, learner is the beginning and end point of learning process, and their needs is focused in educational design. The learner orientation is the learning heart of situated learning that based on constructivist theory. Hence, the goal of E-learning is the realization of situated learning. Based on the theory of situated learning, learning is more effective and efficient when the learner is placed in the actual educational context. It should be noted that the roots of situated learning are empirical learning and problem-based learning (Naidu, 2003).

In addition, educational designers provide learning opportunities for learners and try to not only provide educational materials, but also the content of the course has the necessary dynamics. Successful learning requires a high level of engagement with the content or materials of the learner. Real interaction is activated the learner's mind. Educational materials should be able to activate learning motivation in the learner and involve him in the learning process. The designer should provide an interactive and dynamic environment for users. Interaction is one of the most important features that makes education more effective and enhances learner engagement. Interaction has different forms: active participation and learner engagement, learning through activity, decision making, choosing an option, providing feedback, providing varied options and motivating, are a number of forms of interaction (Clark, 2001). Lynch (2002) states that interacting in the electronic environment is not limited to doing simple activities such as clicking and moving between pages; rather, real interaction requires learner engagement with high-level thinking skills such as composition, application, and interpretation. This type of engagement is created through exploration and involves exposing the learner to an issue, creating problem-solving situations, and inducing the learner to think.

New technologies have reduced some of the limitations of traditional education, such as time and space constraints, so that the learner can synchronize and navigate through the learning environment with using a variety of learning media. But in an E-learning environment, the establishment of human interaction is not possible, and the risk of learning isolation and deprivation of human communication is clearly evident. In this regard, the new 
perspectives of education in order to eliminate human vacuum, in addition to the use of modern facilities, use experiences of participating in real communities of learning and face-toface communication, and emphasizes to integrate traditional and electronic experiences.

Given that the application of information and communication technologies in education enhances the ability of teachers, therefore, they should pay attention to it by recognizing blended learning as one of the new forms of education. The blended learning environment has not been developed in recent years due to its novelty and complexity. This kind of learning, which is considered as a new and evolved version of E-learning, provides a platform for passing traditional education to E-learning. The lack of opportunities to engage in real-world interaction with individuals is one of the key challenges in E-learning. In addition, the E-learning environment lacks in emotional and human communication. Therefore, the present study aims to provide E-learning with traditional blended learning and training for teachers professional development. Therefore, the present study aims to provide E-learning with traditional blended training and training for teachers professional development. Blended training combines the benefits of traditional classrooms and E-learning environments in such a way order to minimize the limitations of both. In this type of Elearning, it is possible to combine in-person training with virtual training to minimize the vacuum of social communication and in-person interaction in E-learning. In the Blended Learning environment, teachers have a sense of being a teacher and no longer worried about where educational media will take their place and reduce their value and dignity. Meanwhile, teachers can find better opportunities for learners to acquire learning opportunities and make their education more attractive and effective by using Information and Communication Technology (ICT) environments (Noroozi and Razavi, 2014). Therefore, it is necessary to evaluate the dimensions and frameworks, how it is designed and implemented in learning environments and the causes of the trend towards this kind of new education in order to explain the presentation of Blended Learning in the development of teachers' professional skills. So the research question is: "Can Blended Learning be used as innovative pattern in teachers' professional development in educational system of Iran?"

\section{Methodology}

The methodology of this research is descriptive-analytic. To this end, the concepts related to the subject of the research have been gathered and the main lines of ideas of ICTs in 
the field of education have been discovered in order to be able to use the set of conceptual sets and structures obtained in order to more accurately explain blended learning because the accurate knowledge of this phenomenon and its proper management in the education system as well as the higher education system are crucial for the transformation of the learningtraining process.

\section{Findings}

Various terms and terminology such as computer-aided education, CD-based education, online education, virtual education, web-based education, online education and other terminology to define the set of training that is provided through computer, multimedia and Internet to the learner is considered as E-learning (H.Samaras, T.Giouvanakis, D.Bousiou \& K. Tarabanis, 2006; A.Zouaq, R.Nkambou \& C.Frasson, 2007) E-learning, Virtual classroom, Virtual schools, Smart schools, and Virtual university are key competences for the development of information and communication technology in education. The fact is that providing a comprehensive definition of E-learning is difficult. However, offering some examples of E-learning helps to understand its meaning:

- Reading an article on web pages;

- Using the World Wide Web, digital libraries and databases for research;

- The use of interactive and multimedia materials in compact format;

-Workshops through e-mail conferencing and webchat;

- Performing a project using the Learning Management System (Noruzi and Razavi, 2014).

Depending on the type of learning method or how the learner supports, there are a number of different types of E-learning that can be considered:

\section{- Static Training Courses:}

In this course, the learner alone is paid to their own learning. In this type of E-learning, the user has no interactions with other educators or learners.

- Virtual Classroom: It uses e-commerce such as computer and network technology to rebuild the structure and experiences of classroom learning. As a teacher in the traditional classroom trains and leads learners and gives them educational materials, the virtual classroom the learner and coach use tools such as e-mail, discussion boards and video conferencing in order to exchange messages. 
- Educational Games and Simulations: In this type, learning is done through simulated activities that require exploration. Learning through gaming and simulation is enjoyable. Games and simulations that follow specific educational goals, in addition to raising interest in the learner, also increase the depth and sustainability of learning.

- Blended Learning: In this type of learning, blended is used from traditional activities and new forms of E-learning. For example, besides traditional classroom activities, learners can receive and exchange messages using e-mail, website and CD (Noroozi and Razavi, 2014).

- Mobile Learning: New technology can be used when a person is not in a stable location and needs to learn. The mobile phone is one of the most flexible information and communication technologies that enable mobile learning (Horton and Horton, 2006).

- Augmenting Teaching: It means that coaches or teachers can boost their teaching using ICT-based experiences. In enriched classes, there may be any type of facility, such as video conferencing and e-mail, to create a discussion between learners and to communicate between the trainer and the learner.

It should be noted that the effectiveness and quality of learning through the electronic environment largely depends on the quality of its design (Horton and Horton, 2006). Creating effective environments requires clever selection of components and their aesthetic composition, tailored to the needs of the audience. Information and communication technologies provide many opportunities for creating learning environments and impressive educational interaction.

The benefits of the correct use of information and communication technology in a blended learning class (network-based) include:

- Establishing a variety of communications and interactions including learner interaction with oneself, learner with human and inhuman factors, learner with education, learner with learner, learner with master and vice versa, learner with content, teacher with teacher, content with content;

- Using a variety of educational media such as models, workshops and laboratories based on educational needs;

- Synchronous and asynchronous communication with other global and local smart classes;

- Effective teamwork implementation;

- Effective implementation of active teaching methods simultaneously in the classroom according to the needs, interests and learning styles of each learner; 
- Classroom management through learning management systems (LMS) and learning content management systems (LCMS);

- Easier past content with new concepts and constructive conceptual design and sustainable learning;

- Ability to provide instant feedback and guidance and easy learning control;

- Link real life learning through simulated environments;

- Attention to high levels of learning and implementation of problem-based learning;

- Provide a platform for the development of learners' mental skills such as metacognitive skills, problem-solving skills, superior thinking and creative thinking through designing a learning environment and challenging exercises;

- Create and maintain a learning and learning motivation in class;

- Ability to use a range of different models of test, test report and record and repeat it;

- Easy to self- evaluation, other evaluation and group evaluation;

- Easy and quick evaluation of input, continuous evaluation (qualitative and quantitative), final evaluation (Pozzi, Manca, Persico, \& Sarti, 2007).

Interaction in the E-learning environment has a variety of dimensions. Wang (2008) considers enhancement of accessibility, utilizing multimedia capabilities, increasing learner control, guiding the learner in the right direction, and cognitive engagement as some of the most important dimensions. Based on these dimensions, he has provided a practical framework for designing interactions in the electronic environment. Educational designer tries to use this framework to enhance interaction in E-learning and apply the following measures to the extent possible in the program (Table 1).

Table 1: Different Dimensions of Interaction Design in E-Learning Environments (Wang, 2008)

\begin{tabular}{|c|c|}
\hline Interactive dimensions & Some measures to increase interaction in the program \\
\hline $\begin{array}{c}\text { Increasing access to } \\
\text { learning }\end{array}$ & Providing users easy access to the program \\
\cline { 2 - 2 } & Adapt the training program with the features of users \\
\cline { 2 - 2 } & Optimize multimedia to speed learner access \\
\hline \multirow{2}{*}{$\begin{array}{c}\text { Utilizing multimedia } \\
\text { features }\end{array}$} & \begin{tabular}{c} 
Use of visual materials to create original learning \\
\cline { 2 - 2 }
\end{tabular} \\
\cline { 2 - 2 } & $\begin{array}{c}\text { Utilizing diverse educational materials to illustrate spatial } \\
\text { and quantitative relationships }\end{array}$ \\
\hline & Configurable and customizable interface design \\
\hline
\end{tabular}




\begin{tabular}{|c|c|}
\hline \multirow[t]{3}{*}{ Increase in learner control } & Providing search and selection information \\
\hline & $\begin{array}{l}\text { Use adaptive measures to increase the proportion of training } \\
\text { with user needs }\end{array}$ \\
\hline & Provide feedback to the learner \\
\hline \multirow[t]{3}{*}{$\begin{array}{l}\text { Provide various learning } \\
\text { paths }\end{array}$} & $\begin{array}{c}\text { Create a learning path compatible with the subject and } \\
\text { learner }\end{array}$ \\
\hline & $\begin{array}{l}\text { Provide diverse learning paths for learners using a branch } \\
\text { program }\end{array}$ \\
\hline & The use of interactive technologies such as upcoming \\
\hline \multirow{5}{*}{$\begin{array}{l}\text { Providing various learning } \\
\text { paths }\end{array}$} & Enable learner's prior knowledge \\
\hline & Stimulates learner curiosity \\
\hline & Create original learning conditions \\
\hline & Using cognitive modeling and scaffolding \\
\hline & the learner to think \\
\hline
\end{tabular}

Blended learning is a descriptive illustration of the combined model of E-learning in the traditional way in which activities and electronic resources are used in conjunction with in-person education (Littlejohn and Pegler, 2007). Horton and Horton (2006) states that Blended learning is not limited to the integration of E-learning and traditional education, but in Blended learning, different forms of learning (Classical and Virtual), educational outlook (Behaviorism, Cognativism, and Constructivism) (Media), educational media (Compact Discs, Websites, Books, Videos, etc.) are merged into one another. This new approach links the real and virtual learning environment.

Blended learning encourages audiences to learn through a variety of methods. Given the fact that Blended learning gives the audience more flexibility to the training course, its design should be valued so that audiences can do their learning activities as well (Noroozi and Razavi, 2014). Blended learning is often used to specify the combination of asynchronous self-learning with the conventional classroom and in-person activity. This kind of combination can easily be validated because traditional schools and universities have used it for 200 years. The instructor in the training section trains the instructor alive, and then it sets the assignment (an asynchronous activity).

In this type of training, traditional learning and E-learning are intended to teach both the learner / learners. Blended learning, in its broad interpretation, is an important opportunity to design a learner-centered curriculum, especially for more and better continuity in the formulation of certificates and degrees. Therefore, blended learning, the optimal combination 
of self-learning, the results of teacher-led leadership and team collaboration, gives each potential in synchronous and asynchronous conditions, appropriate for each learning outcomes.

This learning will include all the tools offered (common, network-based, computerbased), and will select the best combination suitable for the benefit of the beneficiaries (including teachers, learners, and supporting organizations). The network-based offering aims to highlight all three learning styles with varying degrees of growth and success. Successful blended training programs provide all three forms of learning (tutorial, teacher-led outcomes and team-based outcomes) that both applications has been presented in applying (synchronous and asynchronous) in the study program (Jackson and Helms, 2008).

Altogether some of the reasons that educational institutions are offering blended learning are:

1. Improving the quality of in-person learning;

Today, most on-campus universities have set up a learning management system to help improve learning and enhance the effectiveness of the curriculum, by which students use multimedia content, asynchronous exercises and assignments, diverse learning resources, and even access to different evaluation methods.

2. Some of the E-learning universities start their in-class tutoring, depending on the student's level and course of study, then they gradually move toward blended learning courses and then continue their training courses as it's quite electronic.

3. Some of the telecommunication universities will electronically graduate parts of the curriculum to electronize their distance education system and provide other parts in person.

4. Some of the electronic universities, in the absence of sufficient technological infrastructure, carry out some of the courses that they need for laboratory equipment in person.

5. In some countries, educational policies do not allow electronic learning organizations to conduct their final evaluations electronically and necessarily emphasize on-time evaluations. Such policies and plans often require E-learning organizations to use face-to-face practices along with electronic practices.

6. In some universities, a blended learning method is used to provide general and elementary courses that many students choose.

7. The training of some of the jobs that require attendance at the workshop and the actual workplace is not possible through E-learning environments alone, designers and administrators of these courses, in addition to providing E-learning environments, should also 
be assisted in the face-to-face learning environment. In this way, the blended learning environment will form (Seraji and Attaran, 2011).

The perceptions and definitions of blended learning can be categorized into three categories:

- Blended learning as a combination of various electronic and online technologies and tools with in-person training

- Blended learning as a combination of various E-learning and in-person approaches

- Blended learning as a combination of the basics of learning behaviorism and constructivism

King, by considering all sorts of E-technologies and flexibility at the time of teaching, maps out different forms of blended learning as presented in the table below (Table 2) (Seraji and Attaran, 2011).

Table 2: Blended learning from King (2008)

\begin{tabular}{|c|c|c|c|c|}
\hline & \multirow{2}{*}{$\begin{array}{c}\text { In-person } \\
\text { training }\end{array}$} & $\begin{array}{c}\text { Simultaneous } \\
\text { tools }\end{array}$ & $\begin{array}{c}\text { Asynchronous } \\
\text { tools }\end{array}$ & $\begin{array}{c}\text { Learning } \\
\text { materials pre- } \\
\text { recorded }\end{array}$ \\
\cline { 3 - 5 } $\begin{array}{c}\text { Blended } \\
\text { learning Type 1 }\end{array}$ & & & & \\
\hline $\begin{array}{c}\text { Blended } \\
\text { Learning Type 2 }\end{array}$ & & & & \\
\hline $\begin{array}{c}\text { Blended } \\
\text { Learning Type 3 }\end{array}$ & & & & \\
\hline $\begin{array}{c}\text { Blended } \\
\text { Learning Type 4 }\end{array}$ & & & & \\
\hline $\begin{array}{c}\text { Blended } \\
\text { Learning Type 5 }\end{array}$ & & & & \\
\hline Blended & & & & \\
Learning Type 6 & & & & \\
\hline $\begin{array}{c}\text { Blended } \\
\text { Learning Type 7 }\end{array}$ & & & & \\
\hline
\end{tabular}

Applying teaching methods and E-learning and E-learning tools that meet the needs of learners will be effective in shaping the blended learning environment. In the University of Cultural Sciences, due to the numerous capabilities and features of the Blended Learning environment to address existing educational problems due to the lack of some hardware and software platforms and the disadvantages of in-person learning and E-learning, the use of blended learning is recommended and advised for teaching student education. 


\section{Discussion}

With the advent and development of information and communication technology in the field of education and expanding the element of information and knowledge, education systems and learning environments, have changed. Given the pace and depth of the transformation of this technology, understanding this phenomenon and its authentic management in the education system and higher education for drastic changes in the teaching - learning process has a vital role. Important features of ICT are production, distribution and processing information and making it available to everyone in minimal time and cost, without limits of time and space. Nowadays, the most important indicator of development, are the knowledge and efficiency of technology and human thought. ICT development and application of new instruments and concepts through online communication, provides unmatched opportunity for rapid exchange of information and social interactions for learners and causes expansion of information, easy, fast and low cost access. Educational institution as custodian of the education and training can be responsible for the production of knowledge and efficiency in the education process, thereby increasing the knowledge of learners and teachers. In this study tried to combine E-learning with traditional learning and to provide blended learning in teachers' professional development. Since the most important mission of education, is capable and efficient human resourcestraining, it is recommended to use the previous studies and experiences and then relying on culture and indigenous sources.

On the other hand, teachers are the main drivers of networking tools and equipment, and they need to be fully familiar with the new tools, resources and new technologies. Most teachers feel that they are not prepared to use modern technology on educational problems. Professional growth is the main pillar of effective technology use in the classroom. Continuing education should be considered to support and enhance the ability of creative teachers. Information and communication technology is a reliable tool for dealing with the old problems of learning and education. Teachers need the guidance in using the best tools to providing the best instructions. Teachers are expected to help with their technology in their education, but in this way, they will have no help. With the help of the network-based learning environment, teachers find themselves out of loneliness and professional isolation, and feel more attachment to their professional community.

Totally network-based learning environments can help in a variety of ways: 
- Presentation: Animated simulation of scientific issues, contextual presentation and graphic presentation of scientific concepts.

- Expression: the use of text, audio, image, video and media combinations to deliver content and make video footage.

- Participation: Involve learners in the flow of education, during fatigue and frustration.

With the discussion of blended learning, Macdonald (2006) puts forward guidelines and actions for the design and implementation of this type of learning environment. The designer with using the following actions, increase the quality of blended learning:

1. Identify your students well before the course design. Blended learning will not be successful if their knowledge, experiences, and emotions are not properly identified. Information about the learner can be obtained in a variety of ways. For example, using a questionnaire can provide useful information to the designer. Some of this information includes:

- The amount of learner's access time to the internet;

- Basic user skills in using a computer (such as word processing and file management)

- User skills in using the internet (such as searching the web, finding the address, sending E-mail);

- Past learner experiences in learning through the network;

- The method of learner interest, in individually or in group;

- Learning motivation in the designed environment.

2. Explain information for learners about how to learn through this type of education. To accomplish this, teacher can plan a meeting in which learners learn about the course and how to use the tool.

3. In blended learning, scheduling and planning is very important. Providing a learning guideline is good way to plan. It is a helpful tool in the form of printed and designed notes to facilitate student learning. The learning guideline plays many roles such as helping to manage learning, focusing on related learning activities, and providing learners with information about the subject of instruction. Also it is helps the learner to plan his / her time in an optimal way, for various learning experiences such as listening to lectures, using intuitive content, visiting the website and studying CDs.

4. Given that in blended learning, learners are largely responsible for their learning, so use the "Learning Contract" to encourage them to accept learning responsibilities. A learning 
contract is a strategy in which the learner is required to attain a specific learning goal at a given time. In learning contract identifies how to achieve educational goals and to cope with practical challenges, and finally how and when to study (Noroozi and Razavi, 2014).

Totally, there are many kind of content on the internet, including web pages, information and software that teachers use as supplementary educational materials. In some areas, the quantity and quality of instructional materials is low. Many of the content on the internet are not responsive to the interests and needs of students in different cultural or ethnic groups, and are generally based on academic standards or test plans, and also do not emphasize group learning or project-centric activities. Therefore, it is the duty of teachers and educational content providers to work on producing, distributing, classifying and evaluating online content of the highest quality, and expanding the prospects of educational opportunities through the internet.

Teachers use online resources to provide specialized content and resources to their students and encourage them to work outside the classroom and engage with other students and teachers. In this case, expectations of students who are looking for online educational discussions are also met. Information and communication technology offers both the motivation and the opportunity for a broader reform of learning. Learning environments should be rooted in the core of knowledge, social interaction, and evaluation, also emphasize the opportunities for deepening knowledge and attention to the individual needs of learners, and expanding social interaction and collaboration beyond the classroom. New technological tools and gadgets offer a variety of ways to communicate, analyze, and give the opportunity to express views from teachers and students to the educational environment.

Also, we need to pay particular attention to the ICT capabilities to better assess knowledge, competency and better understanding of scientific concepts in the field of learning. Due to the ability to store and send the internet, it is possible to manage the network of tests and assess students' academic activities. The test can provide a variety of questions with varying levels of difficulty. The student can access questions that are consistent with their level of ability. Student feedback can be done quickly to allow better monitoring of all levels of progress, and to adapt your teacher to educational problems or learner learning styles. The use of information and communication technology in both fields of education and evaluation, rather than replicating and storing knowledge, focuses on its thoughtful application. 
So with the use of modern information and communication technology, in addition to online virtual tutorials simultaneously or non-simultaneously, a new type of training, namely Blended Learning, is formed which is combined to traditional classrooms and refers to the territory where traditional and electronic learning is used both for training the learners. Using the Internet and multimedia systems, a variety of tools can be provided to improve the quality of learning and also quick and easy access to information resources and with face to face activities can be prepared interaction element in training. Thus, with the help of technologies and digital media and designing learner-centered curriculum, designing affair, teaching, learning, assessment and evaluation in the electronic learning environment will be optimized. One of the educational systems' necessities in the information era, is cultivation wise and thoughtful teachers in teacher training institutions who are competent in solving modern problems of education and innovating creative solutions.

Therefore, the results show that top of form for this purpose, blended learning (network-based) through new training methods, provides the necessary foundation for improvement the quality of education and training sophisticated teachers and provides effective way to achieve the prominent goals of education. Finally show blended instruction, have changed educational opportunities and the practical tools are available to teachers and instructional designers as well.

\section{Conclusions}

In order to answer the research question, findings show that blended learning can be used as innovative pattern to develop the profession of teachers of Iran's educational system. By blending the capabilities and features of the in-person environment and E-environment, there is an environment where learners with timely flexibility and access to learning resources are actively involved in learning. Such an environment allows learners to develop their needs in accordance with their cognitive and learning styles in order to fulfill their educational goals and support them with diverse resources. Available multimedia in Iran classes' facilities and offer opportunities for continuous study, individual education, lesson review and educational deficiencies. The ability to provide immediate feedback by the teacher has been also provided through communication tools and detailed descriptions. There is also the opportunity to interact with other learners in the form of small groups. 
The blended learning approach has been considered due to fitting with some educational goals and topics, as well as to eliminate some of the limitations of E-learning environments, by providing a learning management system, providing electronic content, designing the learning activities and assignments, providing multiple learning resources, educating learners and creating interactions between them, assessment methods can be implemented. In order to enhance the quality of training courses for the development of teachers professional at cultural university, all curriculum elements can be designed and implemented in person, and then multimedia content, various learning activities, Materials and resources for digital learning and various evaluations are provided in the system to complement classroom education and to be used for the richness of education by designing a learning management system adapted to the training courses.

The ability to apply blended learning and the new design of educational methods in Iran's schools and universities requires a series of related and interlinked actions. So suggestions are presented for using blended learning in the teachers' professional development in educational system of Iran:

- Defining and developing new resources and curricula;

- Creating networks in classes, schools and universities;

- Defining standards and harmonizing content production standards and developing educational resources;

- Providing learning and development objects through work with learning objects;

- Use social networks, forums and discussion boards with blended learning;

- Focusing on inclusive education and individual needs rather than classrooms;

- Use flexible and adaptive technology to recognize human voice and movements translate text to audio, translating language and emotions to change the basis of human communication for blended learning;

- Professional designing of Iranian Teachers' future curriculum for technology and their professional development, to ensure that future generation of teachers benefit from networkbased education opportunities and their continuous growth.

\section{REFERENCES}

Clark, Alan (2001). Designing Computer-Based Learning Materials. Burlington: Gower. Horton, William (2006). E-learning by Design. San Francisco: John Wiley \& Sons, Inc. I Pfeiffer. 
Jackson, M. J., Helms, M. M. (2008). Student perceptions of hybrid courses: Measuring and interpreting quality. Journal of Education for Business, 84 (1), 7-12.

Lynch, Maggie Mc Vay (2002). The Online Educator: A Guide to Creating the Virtual Classroom. London: Routledge.

Littlejohn, Allison, Pegler, Chris (2007). Preparing for Blended E-learning. New York: Routledge.

Macdonald, Janet (2006). Blended Learning and Online Tutoring: A Good Practice Guide. U.S.: Gower.

Naidu, Som (2003). E-learning: A Guidebook of Principles, Procedures and Practices. New Delhi: Commonwealth Educational Media Center for Asia.

Noroozi, Daryoosh, Razavi, Seyyed Abbas (2014). Educational design basics. Tehran: Samt.

Pozzi, F., Manca, S., Persico, D., \& Sarti, L. (2007). A General Framework for Tracking and Analyzing Learning Processes in Computer-supported Collaborative Learning Environments. Innovations in Education and Teaching International, 44 (2), 169-179.

Seraji, Farhad, Attaran, Mohammad (2011). E-learning: Basics, Design, Implementation and Evaluation. Hamedan: Bu Ali Sina University.

Wang, Haomin (2008). A Pragmatic Framework for Promoting Interactivity in E-Learning. In Zheng, Robert and Ferris, Sharmila Pixy (Eds.). Understanding Online Instructional Modeling: Theories and Practices. U.S.: Information Science Reference.

\section{ABOUT THE AUTORS:}

\section{Mahboubeh Fannakhosrow}

Assistant Professor Department of Curriculum, Farhangiyan University of Tehran, Tehran, Iran.E-mail: mfannakhosrow@gmail.com

iD http://orcid.org/0000-0003-4735-8133

\section{Soolmaz Nourabadi}

Assistant Professor, Department of Educational Sciences, Shahed University, Tehran, Iran. E-mail: nourabadi@shahed.ac.ir

(iD http://orcid.org/0000-0001-6524-8240

Recebido em: 26 de outubro de 2019 Aprovado em: 21 de novembro de 2019

Publicado em: 01 de janeiro de 2020 